\title{
Self-Study: A Method for Continuous Professional Learning and A Methodology for Knowledge Transfer
}

Judy C. Woods

None, judy.woods@queensu.ca

Follow this and additional works at: https://qane-afı.casn.ca/journal

Part of the Curriculum and Instruction Commons, Educational Assessment, Evaluation, and Research Commons, Educational Methods Commons, Higher Education and Teaching Commons, Interprofessional Education Commons, Other Nursing Commons, and the Scholarship of Teaching and Learning Commons

\section{Recommended Citation}

Woods, Judy C. (2021) "Self-Study: A Method for Continuous Professional Learning and A Methodology for Knowledge Transfer," Quality Advancement in Nursing Education - Avancées en formation infirmière: Vol. 7: Iss. 2, Article 7.

DOI: https://doi.org/10.17483/2368-6669.1278

This Article is brought to you for free and open access by Quality Advancement in Nursing Education - Avancées en formation infirmière. It has been accepted for inclusion in Quality Advancement in Nursing Education - Avancées en formation infirmière by an authorized editor of Quality Advancement in Nursing Education - Avancées en formation infirmière. 


\section{Self-Study: A Method for Continuous Professional Learning and A Methodology for Knowledge Transfer}

\section{Cover Page Footnote}

This manuscript is submitted as the first of three interconnected studies examining self-study as an approach for continuous professional learning in nursing education. I express appreciation to my committee members, Dr. Lyn Shulha, Dr. Jennifer Medves, and Dr. Peter Chin for their contributions to my doctoral research. To my supervisor, Dr. Lyn Shulha, I express gratitude for your guidance, mentorship, wisdom, and understanding throughout this journey. Ce manuscrit est soumis comme étant la première de trois études reliées analysant l'autoformation comme approche pour l'apprentissage professionnel continu en formation en sciences infirmières. Je tiens à exprimer ma reconnaissance envers les membres de mon comité de thèse doctorale, Dr. Lyn Shulha, Dr. Jennifer Medves, and Dr. Peter Chin pour leur contribution à ma recherche. À ma directrice de thèse, Dr. Lyn Shulha, j'exprime ma gratitude pour son mentorat, sa sagesse, ses conseils et sa compréhension tout au long de mon parcours. 


\section{Introduction}

The purpose of this paper is to authenticate self-study as an effective method for continuous professional learning (CPL) in clinical nursing education. Self-study in this professional learning context (Samaras \& Freese, 2006) is defined differently from self-study in online learning modules (Ens et al., 2016) undertaken for training and study guides for test preparation. In this research, I am the researcher and the participant engaged in self-study as a professional learner endeavouring to become a better clinical nursing instructor (Woods, 2017). My research question is, How does a self-study approach support an instructor's efforts at CPL, specifically about the use of formative assessment in nursing?

Self-study facilitates close examination of my instructional practices as I implement five formative assessment strategies shown to promote student learning in regular classrooms. I appraise their potential in nursing education. Findings of this research also draw attention to selfstudy as a methodology for transferring knowledge about formative assessment from one teaching and learning environment to another. Embedding and examining the new strategies in my work as a clinical instructor facilitates transfer of knowledge about formative assessment between two professions.

In this article, I report findings from the data in relation to the first of three connected studies as researcher and clinical instructor. My goal is to become more competent in professional practice as a clinical instructor, making decisions around formative assessment practices. Formally educated and certified as a registered nurse and a school teacher, I am uniquely positioned to translate and transfer five assessment strategies (Black \& Wiliam, 2009) from the school classroom and implement and examine them in nursing education. Black and Wiliam's research on formative assessment contributed to the broader discipline of Education. Their research examined students' learning in regular school classrooms. In this research, I am examining five formative assessment strategies and studying their potential for promoting nursing students' learning. I am translating and then implementing the strategies in my work as an instructor of 12 students in the simulation lab and 6 students in practicum.

To clarify terminology, I capitalize Education and Nursing when referencing academic disciplines, and I define key concepts as given in Table 1.

\section{Table 1}

Key Concepts

\begin{tabular}{ll}
\hline Concept & Definitions \\
\hline Continuous professional learning (CPL) & "In Education, professional learning is about engaging in \\
& learning activities to increase knowledge and skill in \\
& support of one's professional practice. In Nursing, \\
& professional development is the term used to describe \\
& participating in focused knowledge and competency \\
& development relevant to one's area of practice. Professional \\
& practice standards for Ontario nurses \\
& (www.cno.org/globalassets/docs/prac/41006_ProfStds.pdf) \\
& and Ontario teachers (www.oct.ca/public/professional- \\
& standards/standards-of-practice) require that practitioners \\
& be current in knowledge and competent in practice" \\
& (Woods, 2017, p. 4).
\end{tabular}


Self-study

Formative assessment

Nursing education contexts

Practicum or placement
"In Education, self-study is defined as an approach, a method, and a methodology that facilitates the study of self in a space in relation to other (Bullough and Pinnegar, 2001). Although I was not able to identify any self-study research in Nursing, the purposes of self-study are relevant to Education and Nursing. These are personal and professional growth and development, and improvement in the learning environments (Samaras and Freese, 2006)" (Woods, 2017, p. 4).

"In Education, the definition of formative assessment has evolved and incorporates evaluation for improving conditions for academic learning (Sadler, 1989), assessment as learning (Earl, 2012), and assessment for learning (Black \& Wiliam, 2009). Formative assessment is a familiar term in Education and Nursing. The assessment of clinical performance may be referred to as evaluation instead of assessment" (Woods, 2017, p. 4).

Nursing education takes place in different contexts. These include the classroom, the simulation lab, and clinical practicum.

The terms practicum and placement are used interchangeably and may be preceded by the word clinical when the practicum is situated in a health care setting, such as a hospital. Alternatively, practicum may be community based, such as in a school where nursing students are performing growth and developmental assessments or in a community centre where nursing students are measuring blood pressures.

Theory and practice are two essential components of nursing education programs. Theoretical components of nursing practice are primarily taught in a classroom-style setting such as a lecture hall. An example of nursing education here is a pharmacology course in which nursing students are learning about the classifications of drugs. The practical components of nursing education take place in clinical courses taught in a simulation lab or practicum. A simulation lab is a specially equipped space for teaching clinical nursing skills. An example here is learning how to administer an intramuscular injection. Students learn clinical skills in a simulation lab as preparation for performing these skills in their practicum. In their practicum, supervised by a clinical instructor, nursing students apply knowledge and skill in their provision of care to actual clients. It is in the performance of clinical skills with actual clients that students begin to identify as nurses.

I engaged in self-study as a CPL strategy to become more competent with regard to formative assessment in clinical instruction (Woods, 2018c). Self-study offers "the promise of a professional learning strategy that can help me to better understand the learning needs of my students, to closely examine my instructional practices in relation to those needs, and to adjust my practices as evidence of my own learning (Roessger, 2015)" (Woods, 2017, pp. 4-5). In self- 
regulated professions such as nursing, the self-study method facilitates CPL to advance a practitioner's knowledge, understanding, and competency for practice.

The term CPL in Education (Boud \& Hager, 2012; DiMauro, 2000) describes the improvement orientation of my self-study approach. Learning to be a clinical instructor is a continuous process and not dependent on formalized episodes or educational opportunities. Clinical instructors in Nursing, similar to classroom teachers in Education, tend to work independently. Typically, educators in these professions "rely on the responses and feedback of their students to judge the value and effectiveness of their instruction" (Woods, 2017, p. 4).

The contribution of the formative assessment strategies to learning (Black \& Wiliam, 2009) is particularly important in self-regulated professions, such as Nursing. Registered nurses are accountable for demonstrating knowledge, skill, and continued competency in practice. Selfregulation is a professional expectation and a required competency for improvement of practice (College of Nurses of Ontario, 2002). However, becoming a clinical instructor does not require certification, and instruction for the instructor role is minimal (Bownes \& Freeman, 2020).

\section{The Role of the Clinical Nursing Instructor}

Undergraduate nursing programs are increasingly dependent on part-time clinical instructors to instruct and supervise nursing students in clinical practica, yet programs provide limited guidance to prepare instructors for these important roles. Recently, Bownes and Freeman (2020) surveyed clinical instructors at one Canadian university to explore their perspectives on the worthiness of World Health Organization (WHO, 2016) nurse educator competencies. Bownes and Freeman reported a lack of consensus on the role-specific competencies required by clinical instructors and stated the need to establish competencies for clinical instructors.

Nurses who become clinical instructors face a conundrum. Preparation for the role is limited and core competencies are not defined. The Canadian Nurse Educator Institute (n.d.) offers a clinical instructor certificate; however, this is not a requirement for clinical instruction and the course is targeted at nurses with less than six years of experience.

\section{Background Literature}

\section{Formative Assessment}

Focused on the promotion of students' learning, researchers continue to examine teaching and learning processes from multiple perspectives. In 1969, Bloom employed the term formative to describe assessment that was intended to provide feedback to teachers on the quality of their instruction in promoting student learning (in Wiliam, 2011). In 1983, Ramaprasad examined three key processes for promoting successful teaching and learning: where the learners are going, where the learners are right now, and facilitating learners to the target (Woods, 2017, p. 52). Sadler's (1989) research focused on closing the gap between a student's present state and the state implied by the learning objective, helping students to identify differences between the two. More recently, research in education drew attention to the purpose of assessment through explicit use of the term assessment for learning (Black \& Wiliam, 2009); assessment in the service of learning (Davies \& Herbst, 2013); and attention to the student as a participant, in assessment as learning (Earl, 2003).

Researchers investigate the unique aspects of formative assessment to provoke deeper understanding. 
It was Black and Wiliam, however, who worked directly with classroom teachers over 10 years (1998a, 1998b, 2003, 2007, 2009) to collate assessment strategies that showed the most potential for improving conditions for student learning. The impetus for their program of academic and field-based research was the desire to help students be better prepared to achieve the expectations and standards of performance set out by the curriculum. (Woods, 2017, p. 6)

In their seminal research in education classrooms, Black and Wiliam (1998a) identified five formative assessment strategies shown to promote student learning: (1) clarifying and sharing learning intentions and criteria for success, (2) engineering learning tasks that elicit evidence of student understanding, (3) providing feedback that moves learning forward, (4) activating students as instructional resources for one another, and (5) activating students as the owners of their own learning (Black \& Wiliam, 2009).

\section{Theory of Formative Assessment}

To explicitly distinguish the theory of formative assessment from a theory of teaching and learning, Black and Wiliam (2009) emphasized the critical features of the practice, stating that "it is clear that formative assessment is concerned with the creation of, and capitalization upon 'moments of contingency' in instruction for the purpose of the regulation of learning processes" (p. 10). Formative assessment is thus a contributor to the occurrence of teachable moments (Glasswell \& Parr, 2009; Woods, 2017, p. 29).

Teachable moments occur during teaching and learning activities both inside and outside traditional classrooms.

The term "teachable moment" is common in the professional language of many teachers.

We use it to describe the times when we have found a valuable and authentic opportunity to teach something useful-something we think needs teaching - to someone who needs to learn it and who is ready to learn it right then. (Glasswell \& Parr, 2009, p. 354)

Black and Wiliam (2009) affirmed that for assessment to be considered formative, the instructor, student, and/or student peers must use the evidence collected about student learning to inform next steps in instruction and learning. The assumption is that instructional decisions based on this evidence will more powerfully support learning than decisions made without evidence of how student learning is progressing. Black and Wiliam concluded that using the five formative assessment strategies (Wiliam \& Thompson, 2008) for the purpose of fostering and capitalizing on moments of contingency was the most powerful way to foster student learning and thus formed the core of their theory of formative assessment.

\section{Embedding the Formative Assessment Strategies in Nursing Education}

An introduction to Black and Wiliam's research (2009) influenced my thinking about how strategies found to promote learning in one context (Education) might promote student learning in another (Nursing). Although formative is a familiar term in both Education and Nursing, and its intention is similar, the Education literature explicitly situates formative assessment within the process of learning, advancing towards a summative assessment of learning. This raises the question of how a self-study approach might support an instructor's efforts to embed the formative assessment strategies within the process of learning in Nursing education.

Theoretically, all five of Black and Wiliam's (2009) strategies contributed to student learning by influencing the quality of student thinking and allowing students to be active 
participants in decisions about their learning. These contributions appear particularly appropriate in the education of nursing students. It is critical that nursing students develop an awareness of their strengths and areas requiring improvement and gradually develop independence in monitoring and making decisions about what, when, where, and how learning needs to occur. This skill distinguishes practitioners who are both prepared and capable of assuming responsibility for maintaining their professional competence. If graduating nurses are expected to be continuous professional learners, the pedagogy of clinical instructors should provide students with practice in these self-regulating skills in the transition to becoming nurses (Jennings \& Brett, 2018; Woods, 2017, p. 30).

Clark (2012) proposed that the theory of formative assessment facilitates instruction and improves student learning because it purposefully adapts teaching to meet student needs. Formative feedback, he argued, supports learners' development of "self-regulated learning strategies, which support learning, improve outcomes and actualize the drive for lifelong learning" (p. 205). If classroom research is showing a promising link between formative assessment and students' development as self-regulated academic learners, then it is reasonable to assume that formative assessment strategies will support nursing students in beginning to regulate their learning in a clinical education context.

In nursing, "Koh (2008) supported the argument that formative assessment should be an essential element of pedagogy in nursing and confirmed that students who assumed an active role in the assessment of their learning were able to engage in deeper thinking and were more motivated to engage in learning" (Woods, 2017, p. 31). In professional education, self-regulation and performance are two critically important processes by which

learners personally activate and sustain cognitions, affects, and behaviors that are systematically oriented toward the attainment of personal goals. By setting personal goals, learners create self-oriented feedback loops through which they can monitor their effectiveness and adapt their functioning. (Zimmerman \& Schunk, 2011, p. 1)

It is the responsibility of the instructor to share learning outcomes and success criteria, to embed the strategies in the learning activities, and to provide constructive feedback. It is the responsibility of the student to ask questions to clarify their understanding, to participate in learning activities, to own responsibility for their learning, and to be an instructional resource for peers. Embedding the strategies in the learning activities supports teaching and learning.

Koh (2008) also argued that the real challenge in adopting formative assessment was to "systematically embed formative assessment in curriculum practices and make it a more engaging and rewarding learning experience for both students and teachers" (p. 229). The formative assessment strategies presented by Wiliam and Thompson (2008), Black and Wiliam (2009), and Wiliam (2011) provided a framework for practice with this goal in mind. (Woods, 2017, p. 31)

Wiliam's (2011) guidance for teachers' applying the strategies in classrooms had shaped my own initial efforts at formative assessment and informed my translation of the strategies for nursing education.

\section{What Is Self-Study?}

Historically, the notion of self-study emerged from the work of "a dynamic group of teacher educators committed to studying their practice in an effort to make their teaching, curricula, and/or 
programs more relevant and effective" (Samaras \& Freese, 2006, p. 17). This was the Self-Study of Teacher Education Practices special interest group of the American Educational Research Association. Self-study is recognized as an effective method for examining, understanding, and improving one's teaching practices in teacher education (Capobianco, 2007; Samaras \& Freese, 2006). Recently, Hohensee and Lewis (2019) extended self-study beyond teacher education practices to study peer coaching between experienced teachers in the subject content areas of language arts and mathematics.

Samara and Freese (2006) were early advocates of the "extension of self-study" (p. 18) to other practitioners in other professional contexts. They named the application of this extension self-studyship (p. 18), in hopes of reserving the term self-study for teacher educators (Woods, 2017, p. 33).

I intentionally chose self-study as the term for this professional learning approach. Guided by the self-study of teaching practices literature, I embedded the formative assessment strategies in my work as a clinical instructor and closely examined my formative assessment practices.

In studying my practice as a clinical nurse instructor, however, I felt justified in adopting the term self-study. Like teacher educators, I am responsible for introducing novices to the demands of a highly complex profession. In addition, my goals as a clinical nurse instructor are identical to those of teacher educators, namely, to engage in the close study of my practice as a way to improve my teaching and students' learning. (Lyons, Halton, \& Freidus, 2013; Woods, 2017, p. 33)

Self-study of my instructional practices around formative assessment was a novel approach for my continuous professional learning directed towards becoming a better clinical instructor.

My research draws upon the work of Bullough and Pinnegar (2001), who reported, "to study a practice is simultaneously to study self: a study of self-in-relation to other" (p. 14). My research is a study of my decision making as the clinical instructor in relationship with students who are learning to become nurses. Bullough and Pinnegar went on to clarify that "[self-]study does not focus on the self per se, but on the space between self and the practice engaged in" (p. 15). This self-study research focuses particularly on the space where I enacted formative assessment to observe the meaning of the practice for my students and for me. (Woods, 2017, pp. 5-6)

Furthermore, Bullough and Pinnegar (2001) argued, "the aim of self-study research is to provoke, challenge, and illuminate rather than confirm and settle" (p. 20). I share these goals.

\section{Self-Study as a Method of CPL}

Unique to self-study, it is the individual practitioner who identifies the learning objective(s) relevant to their area of professional practice. In this study, I am the instructor preparing students for their first clinical practicum. I employ self-study as a systematic mode of inquiry, a method to improve my competency as an instructor. As the researcher and participant, I engage in purposeful self-study around five suggested strategies for formative assessment to (a) provoke myself to rethink my instructional practices and how these were or were not supporting student learning, (b) challenge myself to design activities and engage students in new ways, and (c) provide insights into how I might proceed towards the goal of using formative assessment to promote student learning. 


\section{Self-Study Research Design}

In this research I also employ self-study as a particular set of procedures, a methodology to translate and then transfer knowledge about formative assessment strategies from Education to Nursing. Self-study is a methodology in part because of the strong parallels it has to the use of case study as a methodology. Self-study and case studies address research questions that probe for new understandings situated within a specific context. They are research designs or methodologies that address both the what and the so what questions in examining how things work (Stake, 2010).

Engaging in self-study I translated, embedded, implemented, and examined five formative assessment strategies in nursing education. I documented my experiences as the researcher.

Case study and self-study research methodologies are similar in that they can employ a variety of qualitative and quantitative research methods, which ultimately contribute to the creation of context-dependent knowledge (Merriam, 2009). Where they diverge is in their focus. Case study sets the boundaries for inquiry on an "other" person, group, or context (Stake, 2010), while self-study is bounded by the experiences of the researcher. (Loughran, 2007; Woods, 2017, pp. 33-34)

As the researcher, my focus is on critically examining my practices and probing my insider perspectives as the instructor embedding formative assessment strategies in nursing education. I am the researcher and the researched. The question underpinning this research is, How does a selfstudy approach support an instructor's efforts at CPL, specifically about the use of formative assessment? (Woods, 2017, pp. 7-8).

\section{Discussion}

I engaged in self-study and the iterative steps of planning, acting, reflecting, and decision making. Table 2 is a guide to using self-study to support professional learning. The descriptions for each step relate to my professional learning as an instructor implementing formative assessment strategies. Other clinical instructors can use this self-study approach to advance competency in an area of their professional learning interest.

\section{Table 2}

A Guide to Using Self-Study to Support the Professional Learning of Clinical Instructors: A Formative Assessment Example

1. Provoke ideas for addressing my Plan. My objective is to improve my practice of clinical professional learning goal. instruction by embedding formative assessment strategies in my instruction to promote student learning.

2. Describe the implementation of goal- Act. Integrate one or more of the five strategies in each directed practice. learning activity. Observe students' responses to the strategies.

3. Reflect on the implementation and Reflect. Document my reflections on the implementation of consequence of practice. each formative assessment strategy and how these did or did not support my instruction and/or student learning.

4. Make decisions around the next steps. Decision-making. Document new ideas for implementing the strategies in my work as a clinical instructor.

Adapted from source: Woods (2017, p. 76). 


\section{A Formative Assessment Framework}

Attending to the nursing curriculum objectives as guidelines for instruction, and the five formative assessment strategies (Black \& Wiliam, 2009; Wiliam, 2011) as a framework for planning, I examined each strategy and considered how it might inform instruction and learning in nursing education. Translated for nursing education, the formative assessment strategies are:

1. [Clarify, understand, and share] learning intentions and criteria for success.

2. Facilitate discussions and implement learning tasks that provide evidence of students' current understandings.

3. Provide feedback [that is the] most appropriate for moving learning forward.

4. Activate students as instructional resources for one another.

5. Activate students as owners of their own learning (Woods, 2018c).

Translation facilitated nuanced interpretation of these strategies in a new context. Placing emphasis on understand highlights the importance of students fully knowing the target. Stating learning objectives as intentions heightens the requirement for student-focused commitment. Generating evidence of students' current understandings from discussions and learning tasks requires instructors to rethink and redesign activities that allow students to demonstrate evidence of their learning. The description of feedback that is most appropriate for moving learning forward, emphasizes the requirement for and the purpose of formative feedback.

The translated formative assessment strategies provided a framework for instructional planning. Before each instructional episode, I contemplated how to embed the assessment strategies in ways to advance students' learning. Then I documented each iterative step of planning, acting, and reflection in a dedicated journal. An example of operationalizing the first strategy (clarifying, understanding, and sharing learning intentions and criteria for success) was demonstrated in my reviewing specific curricular performance targets for each class and assigning readings related to these. An example of the second strategy (facilitating discussions and implementing learning tasks that provide evidence of students' current understandings) was my circulating among skills' stations as students practised clinical skills and asking questions to evaluate their understanding. Providing feedback that is the most appropriate for moving forward is the third strategy. Appropriate feedback is sometimes corrective feedback given gently and with the intention to promote further learning. An example of the fourth strategy (activating students as instructional resources for one another) involves assigning roles as observer, nurse, or client in a role-playing simulation. Redirecting students to their textbooks and online skill resources to answer questions about procedural steps is an example of the fifth strategy: activating students as owners of their own learning.

Immediately following each instructional episode, I documented actions taken, observations, students' responses to my instructional efforts, reflections, insights, and new decisions. In addition to facilitating systematic documentation of the planning for, implementation of, and influence and consequences of integrating formative assessment in my instruction, the reflection journal supported analysis of the data. Data analysis encompassed the organization of formative assessment strategies by date, clinical skill, and focus for learning; constant comparison (Glaser \& Strauss, 1967) of reflections within each strategy; and identification of themes and patterns within and across strategies. Table 3 is an example of journal reflections on examining the implementation of formative assessment strategies in simulation and practicum. The learning 
objective in the lab is to safely operate a mechanical lift to transfer a client from bed to wheelchair. In practicum, I report on how the strategies were implemented on the second day of the practicum. The learning objective on the second day of practicum is to begin to assist clients with their activities of daily living.

\section{Table 3}

Implementation of Five Formative Assessment Strategies in Nursing Education

\begin{tabular}{|c|c|c|c|c|c|}
\hline $\begin{array}{l}\text { Clinical } \\
\text { context, } \\
\text { date, and } \\
\text { curriculum } \\
\text { focus }\end{array}$ & $\begin{array}{l}\text { Strategy } 1 \\
\text { Clarify, } \\
\text { understand, } \\
\text { and share } \\
\text { learning } \\
\text { intentions and } \\
\text { criteria for } \\
\text { success. }\end{array}$ & $\begin{array}{l}\text { Strategy } 2 \\
\text { Facilitate } \\
\text { discussions and } \\
\text { implement } \\
\text { learning tasks that } \\
\text { provide evidence } \\
\text { of students' current } \\
\text { understandings. }\end{array}$ & $\begin{array}{l}\text { Strategy } 3 \\
\text { Provide feedback } \\
\text { most appropriate } \\
\text { for moving learning } \\
\text { forward. }\end{array}$ & $\begin{array}{l}\text { Strategy } 4 \\
\text { Activate students } \\
\text { as instructional } \\
\text { resources for one } \\
\text { another. }\end{array}$ & $\begin{array}{l}\text { Strategy } 5 \\
\text { Activate students } \\
\text { as owners of their } \\
\text { own learning. }\end{array}$ \\
\hline $\begin{array}{l}\text { Lab \#3 } \\
\text { Date (day, } \\
\text { month, year) } \\
\text { Positioning, } \\
\text { safe lifts, and } \\
\text { transfers, }\end{array}$ & $\begin{array}{l}\text { Reviewed } \\
\text { recommended } \\
\text { readings. } \\
\text { Provided real } \\
\text { clinical } \\
\text { examples of } \\
\text { clients with } \\
\text { varying } \\
\text { medical } \\
\text { conditions who } \\
\text { required lift } \\
\text { transfers to } \\
\text { make explicit } \\
\text { theory-to- } \\
\text { practice } \\
\text { connections. } \\
\text { Demonstrated } \\
\text { use of linen, } \\
\text { transfer slide, } \\
\text { and } \\
\text { mechanical lift } \\
\text { for transfers } \\
\text { from bed to } \\
\text { wheelchair. } \\
\text { Emphasized } \\
\text { safe operation } \\
\text { of equipment } \\
\text { and reviewed } \\
\text { policy for two- } \\
\text { person } \\
\text { operation of } \\
\text { lifts. }\end{array}$ & $\begin{array}{l}\text { Organized skill } \\
\text { stations with a } \\
\text { mannequin in a } \\
\text { bed, linen, a } \\
\text { transfer slide, a } \\
\text { lift, and a } \\
\text { wheelchair for } \\
\text { student practice of } \\
\text { positioning and } \\
\text { transferring. } \\
\text { Required students } \\
\text { working in pairs to } \\
\text { demonstrate safe } \\
\text { transfer of a client } \\
\text { from bed to } \\
\text { wheelchair. } \\
\text { Circulated during } \\
\text { practice to observe } \\
\text { and answer } \\
\text { questions. } \\
\text { Listened to student } \\
\text { comments for } \\
\text { evidence of } \\
\text { understanding. }\end{array}$ & $\begin{array}{l}\text { Acknowledged } \\
\text { students referencing } \\
\text { course resources } \\
\text { when making } \\
\text { suggestions for } \\
\text { transfers. } \\
\text { Identified good } \\
\text { body mechanics. } \\
\text { Commended safe } \\
\text { performance in } \\
\text { positioning and } \\
\text { transfers. } \\
\text { Called attention to } \\
\text { observed unsafe } \\
\text { practices. }\end{array}$ & $\begin{array}{l}\text { Welcomed } \\
\text { assistance of two } \\
\text { students with } \\
\text { mechanical lift } \\
\text { experience from } \\
\text { their work as } \\
\text { PSWs. } \\
\text { Encouraged } \\
\text { teamwork and } \\
\text { clear } \\
\text { communication } \\
\text { with client and } \\
\text { peer in } \\
\text { preparation for } \\
\text { and performance } \\
\text { of safe lift and } \\
\text { transfer. }\end{array}$ & $\begin{array}{l}\text { Referenced pre- } \\
\text { readings and } \\
\text { emphasized the } \\
\text { importance of } \\
\text { student } \\
\text { preparedness for } \\
\text { labs. } \\
\text { Monitored student } \\
\text { discussions and } \\
\text { encouraged use of } \\
\text { procedural steps } \\
\text { and rationale in } \\
\text { course textbook. } \\
\text { Provided } \\
\text { opportunity for } \\
\text { student questions } \\
\text { at end of each lab. }\end{array}$ \\
\hline
\end{tabular}




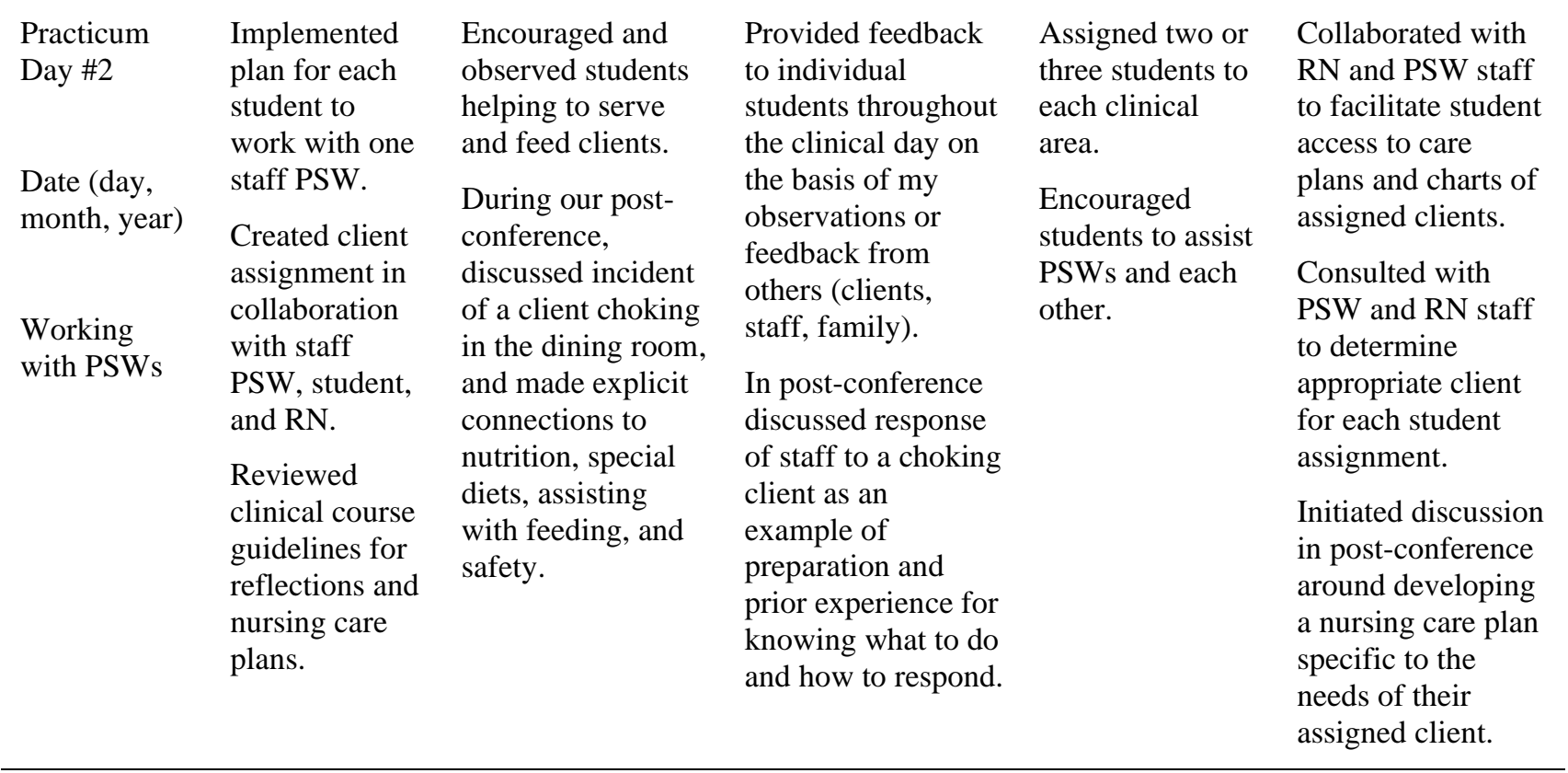

Note: PSW is personal support worker; RN is registered nurse. Based on source: Woods (2017, p 56-57).

\section{Tools of Self-Study}

To improve my instructional practice, I employed the formative assessment strategies as a guide for planning, acting, reflecting, and making decisions for moving forward. In preparation for each instructional episode, I examined each strategy and considered how I might embed the strategies in my instruction. I systematically documented the plan in a dedicated reflection journal. Immediately following each instructional episode, I reflected on my observations and thinking around the contribution of the strategies to student learning. What worked? What did not? What might I do differently next time? I documented these reflections and decisions made around them in the dedicated journal. My instructor toolbox held an instructor manual with course learning objectives, student assignments and evaluation forms, policies and procedures related to the clinical course, and a connection to a course coordinator. I added the essential tools of self-study. These are systematic documentation and iterative cycles of planning, implementation, reflection, and decision-making documented in a dedicated reflection journal.

\section{Description and Interpretation}

Self-study was appropriate for my research because I was not focusing on prediction, explanation, or generalization. Rather, my purpose was to describe, understand, and interpret phenomena of interest, thus aligning my research with an interpretive, descriptive approach (Thorne, 2008). I was challenged to document, analyze, and recursively interpret both what I was learning and what was being learned by my students. I set about to describe my experiences and those of my students, my thought processes and reflections, and the decisions I made when I employed self-study as a form of CPL. I analyzed these data as I went along to better understand how Black and Wiliam's (2009) five formative assessment strategies might be implemented and subsequently how they could influence learning within a clinical educational context. I also used these data to interpret my experiences and those of my students. This process was required to make meaning of our joint efforts. In attending carefully to these responsibilities and positioning my research within an interpretive paradigm (Thorne, 2008) I worked to generate defensible and transferrable insights into the nature of CPL, self-study, and the practice of formative assessment. 
Examining the assessment practices for how they were or were not supporting student learning challenged me as the instructor to design new activities and engage students in new ways. As an example, the students in clinical placement expressed limited confidence in their preparedness for giving intramuscular injections. I acquired syringes, needles, and other supplies, and students practised administering injections on oranges at our next clinical conference. They demonstrated skill development and verbalized feeling more confident.

Iterative cycles of planning, action, and reflection promoted greater understanding of which strategies were effective for particular tasks in each of the simulation lab and the clinical practicum setting. For example, performance of a learned skill in the lab or practicum provides evidence of a student's understanding. Introducing a procedural skill checklist for peer assessment of performance in the lab is a strategy to activate students as an instructional resource for one another. However, it is inappropriate for a student to monitor performance with a checklist in practicum. Instructor decision making around which strategies can be implemented at different times in different places must consider learning intentions and where the learning is taking place. Additionally, analysis provided insights into how one might proceed towards the goal of using assessment to help nursing students better regulate their own learning. Providing clinical skill checklists for pairs of students in the simulation lab to practice suture removal created an opportunity for each to provide and receive feedback from a peer. Taking turns, each student used the checklist to monitor their peer's skill performance and to provide corrective feedback.

Self-study in teaching practices is frequently a cooperative effort between two professionals. One teacher provides constructive feedback to a colleague for the purpose of improving the colleague's teaching practice.

It should be noted that a common feature in the self-study literature is the presence of a critical friend, someone who collaborates in the reflection and gives constructive feedback without judgment. As a clinical instructor I had access to a course coordinator or course professor for urgent student-related needs, but as a contracted part-time adjunct clinical instructor I was not easily identifiable as a faculty member and typically not in regular contact with other nursing faculty. Consequently, I worked primarily independently in an assigned clinical setting with my assigned group of students. Initially, then, only my supervisor and members of my committee, who agreed to check my interpretation of data (Loughran \& Northfield, 1998), were identified as critical friends in my self-study. (Woods, 2017, p. 40)

This is not unlike the participatory mode of thinking (Pepin \& Myrick, 2019) proposed in nursing education. As a clinical instructor, communication and collaboration with instructor colleagues was limited.

\section{Validity of the Study}

As a clinical nursing instructor, the context for my research was never totally independent of the context for my instruction and learning. I engaged in self-study before, while, and after I carried out the formal responsibilities I had as an instructor. My learning, as described in this research, required that I interpret theories and implement recommended practices pertaining to self-study and formative assessment. I observed and documented the consequences of my learning on both my professional practice and on the experiences of students, and I made instructional adjustments on the basis of the quality of outcomes. 
Engaging in self-study as a professional learning approach to improve my instructional practice, I closely examined my instruction in the lab and in practicum. I was instructing clinical skills to nursing students in a simulation lab in preparation for their clinical practicum. In the same semester I was a clinical instructor in practicum with a different group of students. This study was conducted by a real clinical instructor with real nursing students preparing for real nursing practice. Rose (2019) states the

practical value of "real-world" research needs to be viewed in terms of its richness in ecological validity: that is, classroom research is a valid reflection of real-world practices... the practices that make classroom research "messy" are the very reasons it should be valued. (pp. 899-900)

Conducting research into CPL in situ was an effort to add ecological validity to the processes and findings of the inquiry (Gouvier et al., 2010).

\section{Conclusion}

Self-study supported my efforts to translate, transfer, and implement five formative assessment strategies and to examine their potential in nursing education. Although chosen as an approach for my professional learning as a clinical nursing instructor, self-study also facilitated the transfer of knowledge about formative assessment strategies from Education to Nursing.

A reflective journal, systematic documentation, and iterative processes of planning, action, and reflection were the tools of self-study that supported my professional learning about formative assessment strategies. These tools informed my decision-making around translating the strategies and assigning the responsibility for their implementation in nursing education. Additionally, employing the translated strategies as a framework for instructional planning enforced my efforts as the instructor embedding the formative assessment strategies in nursing education.

Close examination of the assessment strategies in nursing education revealed both assigned and shared responsibilities for learning (Woods, 2018b). The instructor had the responsibility for creating conditions for learning pertaining to the learning intentions, creating success criteria, and creating tasks that could provide evidence of the students' current understandings. The instructor also had the responsibility for providing feedback that was appropriate for moving learning forward. Students had the responsibility to attend to and understand, and ask questions, if necessary, about the learning intentions and criteria for success.

The instructor had the responsibility to activate students as instructional supports for their peers and owners of their own learning. Students had the responsibility to assume the role of "learning guide" for each other using learning intentions, criteria for success, instructional tools, and feedback as resources (Woods, 2018b). Students were also assigned the responsibility to selfmonitor their performance and to seek out appropriate feedback and resources to help move their learning forward. All five strategies were found to influence the quality of student thinking and enabled students to be active participants in decisions about their learning.

\section{Limitations, Implications, and Recommendations}

Qualitative methodology has already been demonstrated to have value in building theory and practice related to professional and clinical knowledge in nursing (e.g., Anthony \& Jack, 2009; Thorne, 2008). While a qualitative methodology can encompass a variety of methods, the philosophic stance inherent in the methodology is founded on a constructivist perspective (Merriam, 2009). It is noteworthy that the instructor was both a registered nurse and a certified 
teacher and had developed understanding of assessment strategies in both professions. Familiarity with terminology in both professions supported the translation and transfer of the strategies between different educational contexts, from Education to Nursing.

Although the theory of formative assessment was founded in Education, it has implications for student learning in other contexts. The strategies were shown to be translatable and effective in Nursing education (Woods, 2017, 2018a, 2018b, 2018c). The contribution of embedded formative assessment strategies is not limited to one classroom or one course or one learning environment. In this study, the strategies were embedded in instruction in a simulation lab and in clinical practicum. The rephrased strategies are amenable to integration in different subject content areas. This has implications for future research and education.

This work was completed as part of a larger study that examined self-study as an approach for CPL about formative assessment in nursing education. Self-study, a method for improving teaching practice, was effective for exploring my professional learning interest and holds potential for supporting CPL for other clinical instructors. Nurses are already familiar with the iterative processes of planning, acting, reflecting, and decision-making. These processes are similar to assessment, planning, implementation, and evaluation in the nursing process for providing nursing care.

Furthermore, nursing is a self-regulated profession. Registered nurses are accountable for attaining and maintaining competence for their practice. Students are learning to become nursing professionals.

"It is critical that as nursing students progress through their program they develop independence in determining their learning needs as well as in ascertaining when and how these needs can be addressed. This skill is a distinguishing trait of practitioners who are professionally competent. Graduate nurses are more likely to be continuous professional learners if the pedagogy of their instructors has provided them with practice in these self-regulating skills" (Woods, 2017, p. 21). In this research I embarked on my self-study around formative assessment and translated the theory of formative assessment to my instructional practice with the goal of promoting students' learning (Al-Alawi et al., 2020) and with these points in mind.

Although I was not able to identify any self-study research in the nursing literature, the purposes of self-study, personal and professional growth and development, are relevant to both Education and Nursing. In this research, self-study supported knowledge transfer between two professions and professional learning around the implementation of five formative assessment strategies in Nursing curriculum. As the first known self-study of pedagogical practice in nursing education, this research contributes to building knowledge for scholarship in the profession of Nursing. 


\section{References}

Al-Alawi, R., Oliver, G., \& Donaldson, J. F. (2020). Systematic review: Predictors of students' success in baccalaureate nursing programs. Nurse Education in Practice, 48. https://doi.org/10.1016/j.nepr.2020.102865

Anthony, S., \& Jack, S. (2009). Qualitative case study methodology in nursing research: An integrative review. Journal of Advanced Nursing, 65(6), 1171-1181. https://doi.org/10.1111/j.1365-2648.2009.04998.x

Black, P., \& Wiliam, D. (1998a). Assessment and classroom learning. Assessment in Education: Principles, Policy \& Practice, 5(1), 7-74. https://doi.org/10.1080/0969595980050102

Black, P., \& Wiliam, D. (1998b). Inside the black box: Raising standards through classroom assessment. Phi Delta Kappan, 80(2), 139-148.

Black, P., \& Wiliam, D. (2003). "In praise of educational research": Formative assessment. British Educational Research Journal, 29(5), 623-637. https://doi.org/10.1080/0141192032000133721

Black, P., \& Wiliam, D. (2007). Large-scale assessment systems: Design principles drawn from international comparisons. Measurement: Interdisciplinary Research \& Perspective, 5(1), 1-53. https://doi.org/10/1080/15366360701293386

Black, P., \& Wiliam, D. (2009). Developing the theory of formative assessment. Educational Assessment, Evaluation and Accountability, 21(1), 5-31.

Boud, D., \& Hager, P. (2012). Re-thinking continuing professional development through changing metaphors and location in professional practices. Studies in Continuing Education, 34(1), 17-30. https://doi.org/10.1080/0158037X.2011.6086.56

Bownes, N. A., \& Freeman, M. A. (2020). Clinical nurse instructor competencies: An exploratory study of role requirements. Quality Advancement in Nursing Education, 6(3), Article 5. https://doi.org/10.17483/2368-6669.1226

Bullough, R. V., \& Pinnegar, S. (2001). Guidelines for quality in autobiographical forms of selfstudy research, Educational Researcher, 30(3), 13-21. https://doi.org/10.3102/0013189X030003013

Canadian Nurse Educator Institute. (n.d.). Clinical instructor certification course. http://cneiicie.casn.ca/our-programs/certification-programs/clinical-instructor-certificate-course/

Capobianco, B. M. (2007). A self-study of the role of technology in promoting reflection and inquiry-based science teaching. Journal of Science Teacher Education, 18(2), 271-295. https://doi.org/10.1007/s10972-007-9041-z

Clark, I. (2012). Formative assessment: Assessment is for self-regulated learning. Educational Psychology Review, 24(2), 205-249. https://doi.org/10.1007/s10648-011-9191-6

College of Nurses of Ontario. (2002). Professional standards, revised 2002. https://www.cno.org/globalassets/docs/prac/41006_profstds.pdf

Davies, A., \& Herbst, S. (2013). Co-constructing success criteria. Education Canada, 53(3), 1619. https://www.cea-ace.ca/educationcanada 
DiMauro, N. M. (2000). Continuous professional development. Journal of Continuing Education in Nursing, 31(2), 59-62.

Earl, L. M. (2003). Assessment as learning: Using classroom assessment to maximize student learning. Corwin Press.

Ens, A., Janzen, K., \& Palmert, M. R. (2016). Development of an online learning module to improve pediatric residents' confidence and knowledge of the pubertal examination. Journal of Adolescent Health, 60(3), 292-298. https://doi.org/10.1016/j.jadohealth.2016.10.006

Glaser, B. G., \& Strauss, A. L. (1967). The discovery of grounded theory: Strategies for qualitative research. Aldine Publishing.

Glasswell, K., \& Parr, J. M. (2009). Teachable moments: Linking assessment and teaching in talk around writing. Language Arts, 86(5), 352-361.

Gouuier, W., Barker, A., \& Musso, M. (2010). Ecological validity. In N. Salkind (Ed.), Encyclopedia of research design. (pp. 400-405). Sage Publications. https://doi.org/10.4135/9781412961288.n126

Hohensee, C., \& Lewis, A. E. (2019). Building bridges: A cross-disciplinary peer-coaching selfstudy. Studying Teacher Education, 15(2), 98-117. https://doi.org/10.1080/17425964.2018.1555525

Jennings, A., \& Brett, C. (2018). The pedagogical practices of clinical nurse educators-Les pratiques pédagogiques des infirmières formatrices cliniques. Quality Advancement in Nursing Education-Avancées en formation infirmière, 4(2), Article 7. https://doi.org/10.17483/2368-6669.1142

Koh, L. C. (2008). Refocusing formative feedback to enhance learning in pre-registration nurse education. Nurse Education in Practice, 8(8), 223-230. https://doi.org/10.1016/j.nepr.2007.08.002

Loughran, J., \& Northfield, J. (1998). A framework for the development of self-study practice. In M. L. Hamilton, S. Pinnegar, T. Russell, J. Loughran, \& V. LaBoskey (Eds.), Reconceptualizing teaching practice: Self-study in teacher education (pp. 7-18). Falmer Press.

Loughran, J. (2007). Researching teacher education practices: Responding to the challenges, demands, and expectations of self-study. Journal of Teacher Education, 58(1), 12-20. https://doi.org/10.1177/0022487106296217

Lyons, N., Halton, C., \& Freidus, H. (2013). Reflective inquiry as transformative self-study for professional education and learning. Studying Teacher Education, 9(2), 163-174. https://doi.org/10.1080/17425964.2013.808057

Merriam, S. B. (2009). Qualitative research: A guide to design and implementation. Jossey-Bass.

Pepin, J. I., \& Myrick, F. (2019). Moving forward in nursing education through a participatory mode of thinking - Aller de l'avant en formation infirmière en adoptant un mode de pensée participatif. Quality Advancement in Nursing Education-Avancées en formation infirmière, 5(2), Article 1. https://doi.org/10.17483/2368-6669.1230 
Ramaprasad, A. (1983). On the definition of feedback. Behavioral Science, 28, 4-13.

Roessger, K. M. (2015). But does it work? Reflective activities, learning outcomes and instrumental learning in continuing professional development. Journal of Education and Work, 28(1), 83-105. https://doi.org/10.1080/13639080.2013.805186

Rose, H. (2019). Dismantling the ivory tower in TESOL: A renewed call for teaching-informed research. TESOL Quarterly, 53(3), 895-905. https://doi.org/10.1002/tesq.517

Sadler, D. R. (1989). Formative assessment and the design of instructional systems. Instructional Science, 18(2), 119-144. https://doi.org/10.1007/BF00117714

Samaras, A. P., \& Freese, A. R. (2006). Self-study of teaching practices primer. Peter Lang Publishing.

Stake, R. E. (2010). Qualitative research: Studying how things work. Guilford Press.

Thorne, S. (2008). Interpretive description. Left Coast Press.

World Health Organization. (2016). Nurse educator core competencies. http://who.int/hrh/nursing_midwifery/nurse_educator050416.pdf

Wiliam, D. (2011). Embedded formative assessment. Solution Tree.

Wiliam, D., \& Thompson, M. (2008). Integrating assessment with learning: What will it take to make it work? In C. A. Dwyer (Ed.), The future of assessment: Shaping teaching and learning (pp. 53-82). Taylor \& Francis.

Woods, J. C. (2017). Self-study as a method for continuous professional learning in nursing education [Doctoral dissertation, Queen's University]. QSpace Online Repository. https://qspace.library.queensu.ca/handle/1974/22041

Woods, J. (2018a, May). Embedding formative assessment strategies in clinical nursing instruction [Conference session]. NETNEP 2018 International Nurse Education Conference, Banff, AB, Canada.

Woods, J. (2018b, May). Self-study as a continuous professional learning approach for becoming a better clinical instructor [Conference session]. Canadian Association of Schools of Nursing Conference, Montreal, QC, Canada.

Woods, J. (2018c, October). A self-study approach to embed formative assessment in clinical education [Conference session]. Qualitative Health Research Conference, International Institute for Qualitative Methodology, Halifax, NS, Canada.

Zimmerman, B. J., \& Schunk, D. H. (2011). Self-regulated learning and performance: An introduction and an overview. In D. H. Schunk \& B. Zimmerman (Eds.), Educational psychology handbook: Handbook of self-regulation of learning and performance (pp. 112). Routledge. 